\title{
Historic Caddo Archaeology on the Red and Lower Sulphur River Areas of Northeast Texas
}

Timothy K. Perttula

Heritage Research Center, Stephen F. Austin State University

Follow this and additional works at: https://scholarworks.sfasu.edu/ita

Part of the American Material Culture Commons, Archaeological Anthropology Commons, Environmental Studies Commons, Other American Studies Commons, Other Arts and Humanities Commons, Other History of Art, Architecture, and Archaeology Commons, and the United States History Commons

Tell us how this article helped you.

This Article is brought to you for free and open access by the Center for Regional Heritage Research at SFA ScholarWorks. It has been accepted for inclusion in Index of Texas Archaeology: Open Access Gray Literature from the Lone Star State by an authorized editor of SFA ScholarWorks. For more information, please contact cdsscholarworks@sfasu.edu. 


\section{Historic Caddo Archaeology on the Red and Lower Sulphur River Areas of Northeast Texas}

\section{Creative Commons License \\ (c) (i) (8)}

This work is licensed under a Creative Commons Attribution-NonCommercial 4.0 International License 


\title{
Historic Caddo Archaeology on the Red and Lower Sulphur River Areas of Northeast Texas
}

\author{
Timothy K. Perttula
}

Post-ca. A.D. 1685 Caddo archaeological sites are somewhat surprisingly uncommon on the Red and lower Sulphur rivers in Northeast Texas comparcd to other parts of this broad region (Figure 1). For instance, there are more Historic Caddo siles known in Nacogdoches County in the Neches and Angelina river basin in East Texas (see Middlcbrook 2007) than there are in all of the Red and lower Sulphur river regions.

The low density of Historic Caddo archaeological sites on the Red and lower Sulphur river areas of Northeasl Texas is a product of several factors, the most important likely bcing the rapid abandonment of much of the area after ca. A.D. 1685 because of regional depopulation caused by the introduction of European epidemic diseases. Other factors would include the effects of looting and river flooding that has destroyed sites and collections before they could ever be documented, as well as the overall sporadic nature of professional archaeological research along these rivers in the Caddo area. A committed and long-term Historic Caddo archaeological and ethnohislorical research program along the Red and lower Sulphur rivers is long overdue.

Post-ca. A.D. 1685 Historic Caddo sites on the Red and lower Sulphur are recognized from two kinds of archaeological materials. These include European trade goods of glass, melal, and wheelmade ceramics (Table 1), generally more common in post-A.D. 1720 contexts, as well as certain kinds of distinctive decorated Caddo pottery wares, particularly engraved fine wares (Table 2) such as Natchitoches Engraved and varieties of Simms Engraved and Avery Engraved, along with Keno Trailed, var. Phillips. Emory Punctated-Incised (some with constrictcd necks), Nash Neck Banded, and McKinney Plain types are important decorated ulility wares in these two locales.

In this article, I provide short summarics of the current state of archaeological knowledge aboul the Historic Caddo settlement of the Red and lower Sulphur river areas of Northeast Texas. Most of that knowledge, for better or worse, from some specific areas derives from the excavation of Caddo burials, rather than from detailed investigations of habitation contexts.

\section{CLEMENTS AND GOODE HUNT SITES}

The Clements (4ICS25) and Goode Hunt (41CS23) sites are in the Black Bayou drainage near the Caddo Trace (sce Figure 1). Both these sites, and the A. P. Fourche and R. A. Simpson sites in the same drainage, appear to represent late $17^{\text {th }}$-early $18^{\text {th }}$ century upper Nasoni Caddo settlements and cemeteries (Gonzalez et al. 2005:12-13) (Figure 2).

The only European trade goods from these sites are small samples of pre- 1700 medium-sized opaque blue glass beads from a few burials at the Clements site. The diverse and distinctive aboriginal material culture from these Nasoni Caddo sites includes non-shell-tempered ceramic bolles (44\%), carinated bowls ( $29 \%)$, jars (15\%), bowls $(6 \%)$, and compound bowls (6\%) of Taylor Engraved, Simms Engraved (including var. Darco) and Simms Plain, Hodges Engraved, including bilobed and spoolnecked bottles, Keno Trailed, var. Phillips, a redslipped jar, and Hatinu Engraved types. Also found on these Historic Caddo sites are elbow pipes and clay figurine fragments, large chipped stone knives and ground stone celts of several forms, marine shcll beads, Clements style shell discs (Perttula and Green 2006), shell zoomorphic pendants (also present at the Sam Kaufman/Roitsch site in a Historic Caddo burial), and gorgets, bone and shell tools (perforated hoes), and an abundant use of clay pigments (Gonzalez el al. 2005:25-53). 


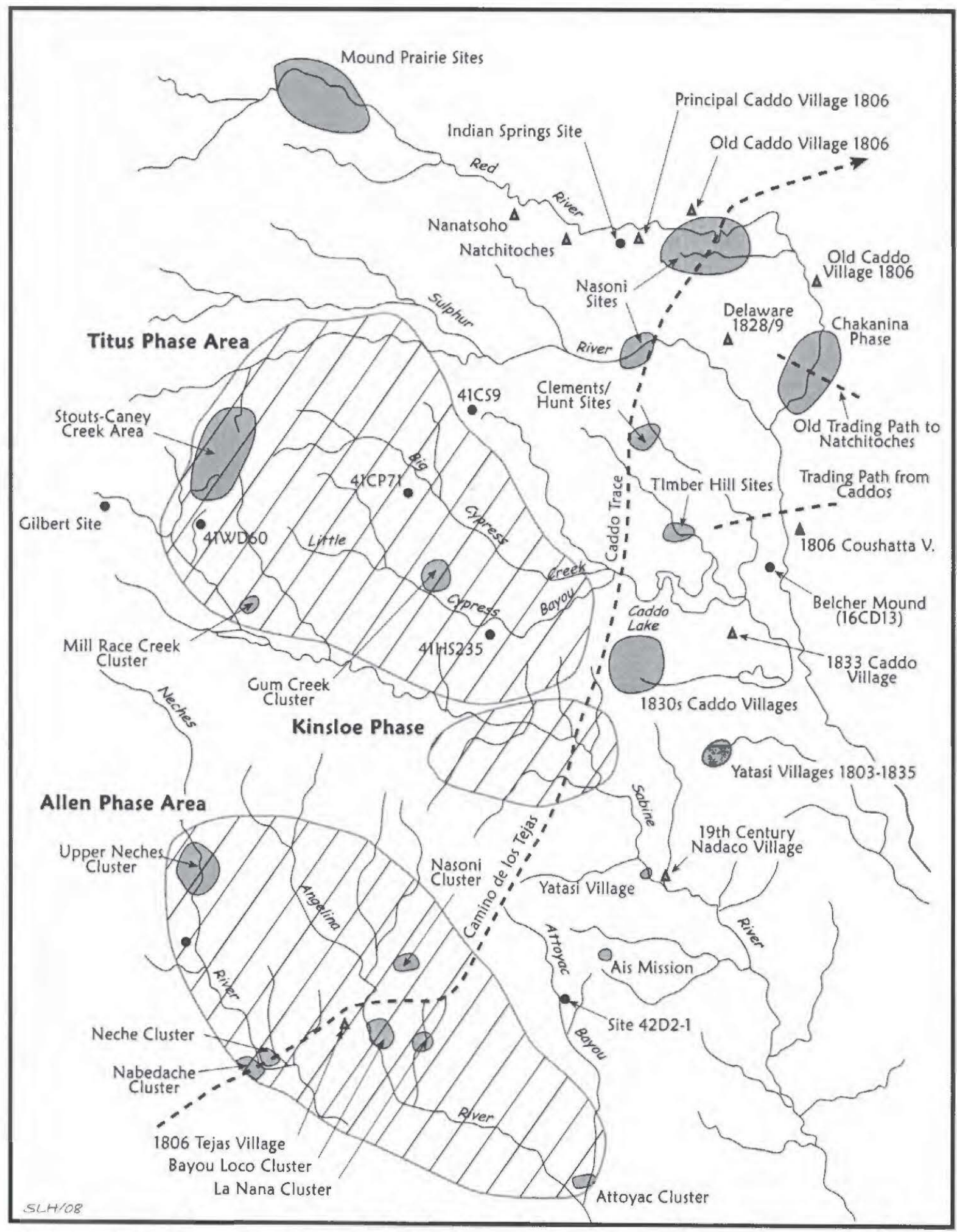

Figure 1. Historic Caddo sites and phases in Northeast Texas. 
Table 1. Trade Goods on Historic Caddo Sitcs on the Red and lower Sulphur rivers in Northeast Texas.

\begin{tabular}{|c|c|c|c|c|c|c|}
\hline \multirow[t]{2}{*}{ Trade Good } & \multicolumn{3}{|c|}{ Pre- $1700 / 1720$} & \multirow{2}{*}{$\begin{array}{l}\text { 1720-1780s } \\
\text { Roscborough } \\
\text { Lake area }\end{array}$} & \multirow{2}{*}{$\begin{array}{l}\text { pre-1720 } \\
\text { Mound } \\
\text { Prairie }\end{array}$} & \multirow{2}{*}{$\begin{array}{c}1700-1730 \\
\text { Womack } \\
\text { site } \\
\text { area }\end{array}$} \\
\hline & $\begin{array}{l}\text { Clements } \\
\text { area }\end{array}$ & $\begin{array}{c}\text { Atlanta } \\
\text { SP } \\
\text { area }\end{array}$ & $\begin{array}{c}\text { Hatchel } \\
\text { area }\end{array}$ & & & \\
\hline Glass beads & + & + & + & + & + & + \\
\hline Gun parts & & & & + & + & + \\
\hline Iron knive & & + & & + & + & + \\
\hline iron awl & & + & & & & + \\
\hline Iron disk & & & & & + & \\
\hline Brass bracelet & & + & & & & \\
\hline Tinkler & & & & & + & + \\
\hline Copper point & & & & & + & \\
\hline Gunflints & & & & + & & + \\
\hline Bullet/ball & & & & + & & + \\
\hline Brass beads & & & & & & + \\
\hline Sword guard & & & & & & + \\
\hline Axe/wedge & & & & + & & + \\
\hline Horse parts & & & & + & & + \\
\hline Strike-a-lite & & & & & + & + \\
\hline Kettle parts & & & & + & & + \\
\hline Hawk bell & & & & + & & + \\
\hline \multicolumn{7}{|l|}{ Brass/lead } \\
\hline disk & & & & & & + \\
\hline Pendant/medal & & & & + & & + \\
\hline Button & & & & + & & + \\
\hline Glass mirror & & & & + & & + \\
\hline \multicolumn{7}{|l|}{ European } \\
\hline ceramics & & & & + & & + \\
\hline Bottle glass & & & & + & & \\
\hline Scissors & & & & + & & \\
\hline
\end{tabular}

$+=$ presence

\section{LOWER SULPHUR RIVER AREA}

Certainly the best known Historic Caddo site on the lower Sulphur River is the Atlanta State Park site (41CS37) along the Lakc Wright Patman shoreline (Harris et al. 1980). Other Historic Caddo components known at this lake include 41BW65 (Lawrence Head, 2003 personal communication) and 41CS5. These sites are also likely affiliated with the Nasoni Caddo (see Figure 2).

Excavations at the Atlanta State Park site recovered shell-tempered vessels of Natchitoches Engraved, Nash Neck Banded, and Emory
Punctated-Incised in burials, along with associated European trade goods, including glass beads, iron clasp knives, an iron awl, and a brass bracelet (Harris et al. 1980). Habitation deposits from the same component contained sherds from Natchitoches Engraved, Emory Punctated-Incised, Avery Engraved, Simms Engraved, Nash Neck Banded, and McKinney Plain; the relative frequency of shell tempering in the vessel sherds found in habilation areas was not provided in Harris et al. (1980), but may have been substantial based on the kinds of ceramic types represented in these deposits. If this is an accurate charactcrization, these Nasoni 
Table 2. Aboriginal Ceramics on Historic Caddo Sites on the Red and lower Sulphur river areas in Northeast Texas.

\begin{tabular}{|c|c|c|c|c|c|}
\hline Pottery type & $\begin{array}{l}\text { Clements } \\
\text { area }\end{array}$ & $\begin{array}{l}\text { Atlanta } \\
\text { SP arca }\end{array}$ & $\begin{array}{c}\text { Hatchel/Roseborough } \\
\text { Lake area }\end{array}$ & $\begin{array}{c}\text { Mound Prairie } \\
\text { area }\end{array}$ & $\begin{array}{l}\text { Womack } \\
\text { site }\end{array}$ \\
\hline \multicolumn{6}{|l|}{ Engraved wares } \\
\hline Natchitoches & & + & + & + & + \\
\hline Simms & $+^{*}$ & + & $+^{*}$ & $+^{*}$ & + \\
\hline Avery & & + & + & + & + \\
\hline Belcher & & & + & & \\
\hline Hodges & + & & + & & \\
\hline Bailey & + & & & + & \\
\hline Hudson & & & & + & + \\
\hline Womack & & + & + & & + \\
\hline Taylor & + & & & + & \\
\hline Hatinu & + & & + & & \\
\hline \multicolumn{6}{|l|}{ Trailed } \\
\hline \multicolumn{6}{|l|}{ Keno, var. } \\
\hline Phillips & + & & + & + & \\
\hline \multicolumn{6}{|l|}{ Trailed-Inciscd } \\
\hline Foster T-I & & & + & & \\
\hline \multicolumn{6}{|c|}{ Other utility wares } \\
\hline Nash $\mathrm{Nb}$ & & + & + & + & \\
\hline McKinney Pl. & & + & + & + & \\
\hline Emory P-I & & + & $+* *$ & $+* *$ & + \\
\hline Cass App. & + & & & & \\
\hline Clements B & + & & & & \\
\hline Brushed-Punct. & + & & & & \\
\hline Shell temper & $<5 \%$ & $? ?$ & $\begin{array}{c}<3 \%, \text { pre- } 1720 \\
>63 \% * * *, 1720-1780\end{array}$ & $90 \%$ & $44 \%$ \\
\hline
\end{tabular}

+=presenec; $\mathrm{T}-\mathrm{I}=$ =lrailed-incised; $\mathrm{Nb}=$ neck banded; $\mathrm{Pl}$ =plain; $\mathrm{P}-\mathrm{I}=$ =punctated-incised; $\mathrm{App}=$ appliqued;

B=brushed; *Simms Engraved, var. Darco (Perttula 2007a:118); ${ }^{* *}$ constricted neck punctated vessels are present; ***at Roseborough Lake (Miroir et al. 1975; Gilmore 1986), but not Indian Springs \#2, where shelltempered pottery is not present (Perttula 2005:44).

Caddo had a ceramic tradition based on the use of shcll tempering, while other possible Nasoni Caddo groups living to the north-northcast (on the Red River) and the south (along Black Bayou) made their ceramic vessels primarily with grog and/or bone (see Figure 2).

The Old Moore Place (41CS5) at Lake Wright Patman on the lower Sulphur has an Historic Caddo archacological component, based on the documentation of a small collcction held by Paul Schoen of Texarkana (notes and photographs on file at the Arkansas Archeological Survey, Southcrn Arkansas University offices). A single burial here contained Natchitoches Engraved and Womack Engraved vessels, 1265 glass beads, iron knives, and a copper bracelet. 


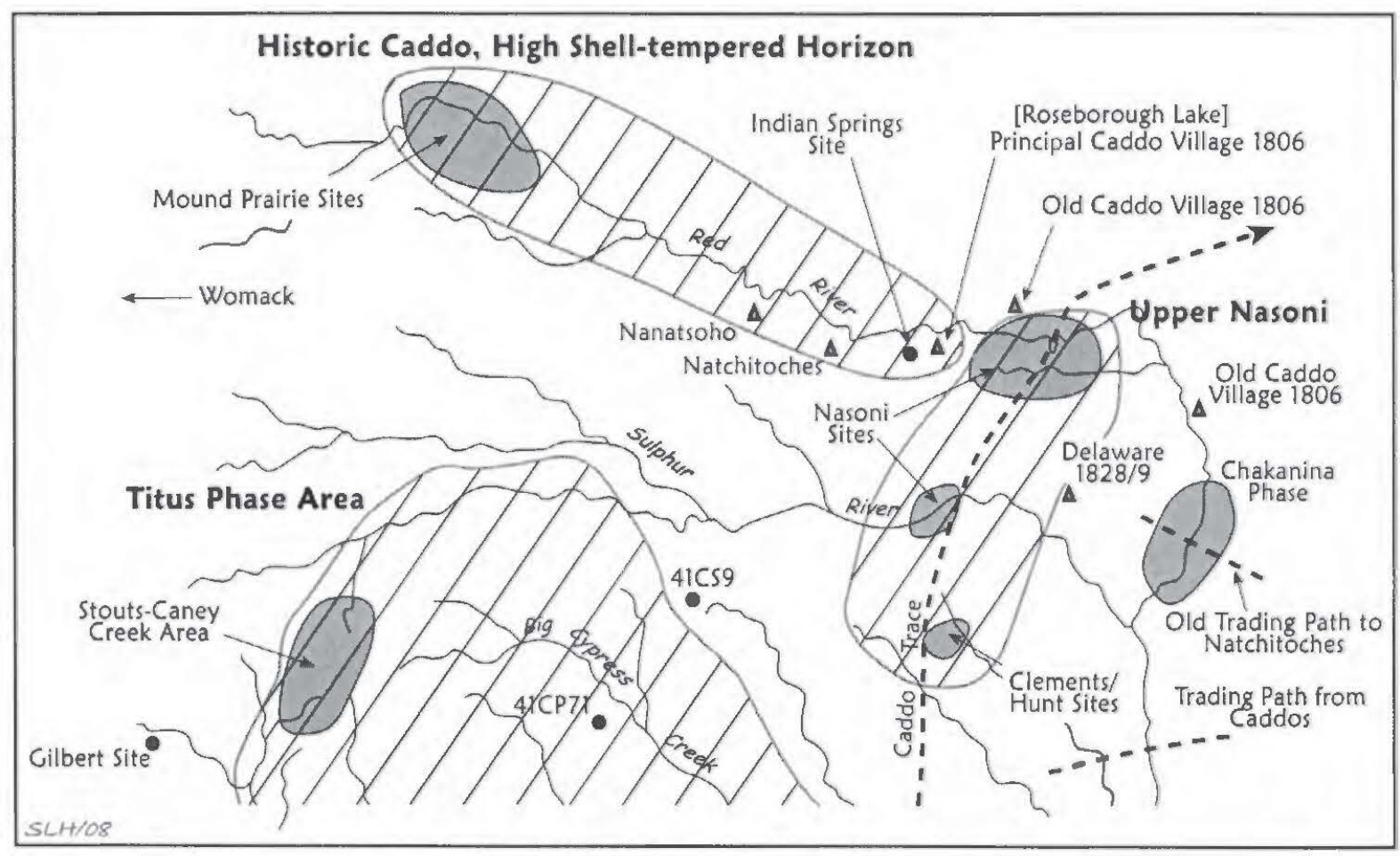

Figure 2. Upper Nasoni areas on the Red and Sulphur rivers.

\section{Hatchel site and environs on the Red River}

Several sites along the Red River in eastern Bowie County, Texas, were occupied in Historic Caddo times, including the Hatchel (4IBW3), Eli Moores (41BW2), and Horace Cabe (41BW14) sites. It is well known that these Caddo sites are found within the large Nasoni Caddo village area mapped by Don Domingo Teran de los Rios in 1691 along this part of the Red River, with the templo or temple mound depicted on that map apparently the large platform mound at the Hatchel site (Wedel 1978:Figure 2).

Historic European trade goods are rare in the Hatchel site and environs, being restricted at present to a handful of late $17^{\text {th }}$-early $18^{\text {th }}$ century glass beads from Hatchel, Eli Moores, and Cabe, and two lead balls in a burial at Eli Moores (Gilmore 1991). In each case, the glass beads are uniformly small and drawn varieties of blue and white colors, and either opaque or clear. A collection of 111 glass beads colleeted from the Horace Cabe site (now at the Texarkana Museum Systems) is dominated by small opaque blue beads ( $90 \%$ ), with a few small white and clear turquoise beads and two rounded Cornaline d'Aleppo beads. Small blue and aquacolored beads are reported from Eli Moores, and a few small drawn opaque blue beads are in the Hatchel site collections at the Texarkana Museums System. The prevalence of small blue and white beads and the lack of large and medium-sized beads and polychrome beads is generally consistent with pre- 1700 beads.

With respect to the aboriginal material culture on these Nasoni sites, shell-tempered ceramics comprise less than $3 \%$ of the sherds from the Hatchel site village (Perttula and Nelson 2003). Engraved and trailed sherds from Simms Engraved, Taylor Engraved, Hodges Engraved, and Keno Trailed vessels are predominant in the different village areas, along with Foster Trailed Incised, McKinney Plain, Karnack Brushed-Incised, and Simms Plain. The same range of ceramic types are represented in the vessels found in association with ca. A.D. 1650-1700 burials in the village, along with examples of Avery Engraved, Belcher Engraved, and Nash Neck Banded. A few sherds are from red-slipped vessels. There are plain elbow pipes in the Hatchel site component, along with Maud arrow points and other chipped stone tools made from local Red River gravels.

The available archaeological information from the Hatchel site and other nearby Nasoni Caddo sites suggests that they were occupied as early as the $13^{\text {th }}$ century A.D, and were probably continuously 
occupied through the $17^{\text {th }}$ century. They do not appear to have been occupied by these Caddo much after ca. A.D. 1720, however.

The Moore/Higginbotham site (3MI3/30), a large Caddo town about 10 milcs downstream from Hatchcl, appcars to have also been occupied in the late $17^{\text {th }}$ and early $18^{\text {th }}$ centuries, bascd on sherd collections (almost exclusively non-shell-tempered) from several different parts of the village (Kelley and Guccione 2000) that are much like those from the village areas at Hatchcl. More importantly, a Keno Trailed, var. Phillips vessel has been documented in a collection of more than 150 vessels from the site in the hands of the ranch manager. However, there is no available evidencc to suggest that Moore/ Higginbotham is the old Caddo village depicted on 1806 maps of this part of the Red River (see Figure 1) (depicted as being on the north side of the river, while Moore/Higginbotham is on the south side of the river), as has been posited by Sierzchula et al. (1995). Such a site would have been occupied into the 1780s, and European trade goods and Natchitoches Engraved vesscls would be expected to be common, but they are notably absent at the Moorcl Higginbotham site.

An examination of the whole vessel records and photographs at the Arkansas Archeological Survey, Southern Arkansas University office indicates that there are few known Historic Caddo sites that have been documented on the Red River downstream from the Hatchel site and environs in the Great Bend area (see Figurc 1). Natchitoches Engraved vessels, the primary Historic Caddo ceramic diagnostic, have been found at the following sites in the Chakanina phase area: Battle (3LA1), Spirit Lake (3LA83), 3LA89, and Cedar Grove (3LA97). Keno Trailed vessels - some varieties of which represent important post-A.D. 1600/1650 Historic Caddo ceramic vessels-have only been documented from Battle (var. Scott's Lake) and Cedar Grove (var. Glendora and var. Phillips), as well as Lester Place (var. McClendon). Lastly, European trade goods have also been reported from a burial at the Foster site (3LA27), but their context and any associated Caddo archaeological materials is not currently known (David Jeane, November 2007 personal communication).

\section{Roseborough Lake and Indian Springs \#2 sites on the Red River}

The Roseborough Lake (41BW5) and Indian Springs \#2 (41BW512) sites are located a few miles upstream on the Red River from the Hatchcl and Eli Moores sites. Both are Caddo habitation sites with cemeteries and village areas, but Roseborough Lake site appears to have been the village where La Harpe erected a trading post in 1719 and the later post of San Luis de Cadohadacho, established ca. 1731-1733 and maintained until the 1780s (Gilmore 1986:13-17). The Indian Springs \#2 site was also apparently a Kadohadacho site, although the specific group is nol known. It is located on the Red River not far from the historic placement of the Nanatsoho and upper Natchitoches Caddo groups (Swanton 1942:Figure 1; see Figure 2, this article).

The Caddo ceramics from $18^{\text {th }}$ century contexts at the Roseborough Lake site are heavily shelltempered (63-70\%, see Miroir et al. 1975; Gilmore 1986), with the remainder tempered with grog or bone; conversely, no shell-tempered vesscls or sherds were identificd at the Indian Springs \#2 site (Perttula 2005). The considerable numbers of shelltempered vessels and sherds at Roseborough Lake suggest a ceramic tradition that was affiliated with other Caddo groups living some distance upstream along the Red River (see Figure 2).

Important engraved fine ware vessels include Natchitoches Engraved (shell and non-shell-tempered), Womack Engraved (non-shell-tempered), and Simms Engraved (both shell and non-shell-tempered), including var. Darco from the Indian Springs \#2 site, along with shell-tempered McKinney Plain, Emory Punctated-Incised (shell and non-shell-tempered), including a constricted neck form (Gilmore 1986), Keno Trailed (non-shell-tempered), and an incised and noded jar (non-shell-tempered). There are two small plain jars from the Indian Springs \#2 site. Other clay artifacts from these Kadohadacho sites include ring foot or ring base engraved elbow pipes (Miroir et al. 1975:Figurc 6c-d), figurines (including one horse figurine, see Miroir et al. 1975:Figure 6e), and pendants. The chipped stone tool assemblage is dominated by triangular arrow points (identified as the Fresno type, as at Womack), unifacial and bifacial scrapers, and drills. Miroir et al. (1975) also mentions marine shell beads and pendants and mussel shell spoons.

Glass beads are abundant at both of these sites. These glass beads from the Roseborough Lake and Indian Springs \#2 sites date later in the $18^{\text {th }}$ century, from ca. $1720-1780$ or thereabouts than those from the Hatchel site and environs, and are characterized by some medium to large drawn and tubular beads, many small drawn beads (72-95\%), as 
well as a few striped heads and wire-wound beads, and considerable numbers of Cornaline d'Aleppo beads. These assemblages are more typical of later $18^{\text {th }}$ century French Louisiana bead collections (see Smith 2002).

A wide variety of other kinds of European trade goods come from the Roseborough Lake and Indian Springs \#2 sites, indicating that the Caddo groups living there had ready access to European goods through a good part of the $18^{\text {th }}$ century. These were most likely obtained from French traders living in this part of the Red River vallcy who were trading goods of various sorts for deer hides and other Caddo products. At Roseborough Lake, other than beads, there are European ceramic sherds (from faience, delft, majolica, and German stoneware vcssels), bottle and mirror glass, horse trappings, knives, axes, scissors, pendants, and bells, copper and brass kcttles, as well as gun parts, gunflints, and lead shot (Miroir et al. 1975; Gilmore 1986). The much smaller assemblage from Indian Springs \#2 had blade gunflints, an iron casc knive, a musket side plate, and a copper kettle bail ear (Perttula 2005).

\section{Mound Prairie area}

Historic Caddo archaeological materials have been reported from the Wright Plantation site (41RR7) on Mound Prairie; the site is situated across from the mouth of the Kiamichi River, a natural gateway through the Ouachita Mountains to the Arkansas River valley (Williams and Schambach 2002:16). These historic archaeological materials include Natchitoches Engraved vesscls, a few glass beads, and gun parts, presumably from burials at this extensive and multi-component village. The R. King Harris Collection at the National Museum of Natural History, Smithsonian Institution, has these materials, which have not been fully documented.

At the Sam Kaufman/Roitsch site (41RR16) on the Red River, $11 \%$ of the 37 reported Caddo burials excavated here since the early 1950 s contained European trade goods that appear to predate ca. A.D. 1720 (Harris 1953; Skinner et al. 1969; Pcrttula ct al. 2001; Perttula 2008; Banks and Banks 2002). These burials wcre in the East Mound or in separate cemctcries across the site. Harris (1953) noted that blue glass beads, copper tinklers, and a copper awl, as well as a zoomorphic marine shell pendant (of the same style as several found at the Clements site), were found in Burial 9 along with shell-tempered vessels of Nash Neck Banded and Hudson Engraved. Burial 16 had two glass beads and a wide assortment of shell-tempered ceramic vessels, including Hudson Engraved, red Avery Engraved, Simms Engraved (including var. Darco, see Skinner et al. 1969:Figurc 21a, c), Nash Neck Banded, Kcno Trailed, var. Phillips (see Skinner et al. 1969:Figure 19f), and Emory Punctated-Incised, including one with a constricted rim neck (Skinner et al. 1969:Figure 16g). A singlc blue glass bead came from the fill of Burial 31, along with marine shell disk and tubular beads and bone beads (Perttula ct al. 2001:190; Perttula 2008:368 and Figure 41). Finally, Banks and Banks (2002:Plate 18) report the excavation of a Caddo burial in another part of the Roitsch site that had a small iron knive fragment in the grave pit, along with shell-tempered Avery Engraved, Simms Engraved, Bailey Engraved, Nash Neck Banded, and a plain bowl or jar. Other associated funerary offcrings were Talco arrow points, a ground stone celt, and a marine shell disk. A 2-sigma calibrated radiocarbon date from this burial ranges from AD 1430-1630, suggesting possible European contact with the Caddo living at Sam Kaufman/Roitsch some time prior to the mid- $17^{\text {th }}$ century.

The Bob Williams site (Perino 1983) is another part of the larger Sam Kaulman/Roitsch Caddo village. Two burials there had trade goods (an iron disk and iron strike-a-litc) along with shell tempered Hudson Engraved, Taylor Engraved, Avery Engraved, McKinney Plain, and Emory PunctatedIncised vessels, an appliqued jar, an engraved elbow pipe, and Maud arrow points; blue glass beads have been found on the site surface.

Two of the Emory Punctated-Incised jars from Bob Williams, including one from one of the burials with European trade goods, have distinctive incised curlicue lines (or a hooked vertical scroll) on the vessel body (Pcrino 1983:Figure 7c). This variety of Emory Punctated-Incised, with two or three horizontal rows of punctations on the rim, is also prescnt in late $17^{\text {th }}$ century-early $18^{\text {th }}$ century burial contexts at the Roden site (34MC215) (Perino 1981:80) and Sam Kaufman (Harris 1953:Plate 8, no. 5). At Roden, this particular stylc of Emory Punctated-Incised was found in a burial in association with Hudson Engraved, Taylor Engraved, Simms Engraved, Avery Engraved, and smoothed Nash Neck Banded vessels. An engraved version of this curlicue body clement is present on a redslipped jar from an undocumented Caddo sitc in the 
Great Bend of the Red River (Bond 2006: Figures 395 and 395a).

\section{Womack site}

The Womack sitc (41LR1) is well up the Red River from the Mound Prairie area. The glass beads found here from several burials and in habitation contexts suggests that it was likely occupied by a Caddo group between ca. 1700-1730. The Norteno or Kichai attribution to this occupation by Harris et al. (1965) and others simply does not accord with the stylistic character of the recovered ceramic vessels and sherds found in burials and habitation deposits at the site. Womack Engraved, on further consideration, appears to be a distinctive Caddo vessel form with a constellation of certain stylistic elements and motifs developed in the upper Sulphur, upper Cypress, and upper Sabine river basins (Perttula 2007b:142).

The principal ceramic types at the Womack site are four varieties of Womack Engraved and Emory Punctated-Incised. The Womack Engraved vessels and sherds are rarely shell-tempered $(<9 \%$; described by Harris et al. [1965] as grit-tempered) while the Emory Punctated-Incised vessels are commonly shell-tempered (86\%). Except for the plain shcrds, most of the other pottery types present at Womack are shell-tempered; these vessels may have been manufactured downstream in the Mound Prairie area or even the vicinity of Roseborough Lake, where a shell-tempered pottery tradition had been in existence among the Caddo since at least ca. A.D. 1300 and the Historic Caddo sites in this area have a high percentage of shcll-tempered vessels (see Figure 2), or the Caddo living at the Womack sitc manufactured both kinds of tempered pottery wares.

The abundance of trade goods at the site (see Table 1 ) in this early $18^{\text {th }}$ century context is notable. Combining this with the virtual absence of such goods from contemporaneous Caddo sites downstream suggests that these trade goods may have reached the Womack site Caddo either through overland routes from Arkansas River trading posts or from the post-1719 French trading post established in the vicinity of the Roseborough Lake site by La Harpe.

Another notable characteristic of the Womack site artifact asscmblage is the extensive chipped stonc tool assemblage documented here. This assemblage includes more than 860 arrow points, 89 chipped stone knives, and more than 870 scrapers of various forms (Harris et al. 1965). This assemblage of hunting and hide preparation tools-in conjunction with the large range of European trade goodssuggests that the Caddo living here were already hcavily involved in the deer hide trade.

\section{CONCLUSIONS}

Several different Caddo groups lived along the Red and lower Sulphur rivers in the late $17^{\text {th }}$ century and much of the $18^{\text {th }}$ century, at least in certain arcas (see Figures 1 and 2). European trade goods are uncommon in Caddo sites in these areas until after ca. 1720 (see Table 1), except perhaps at the Womack site well up the Red River, where its Caddo inhabitants appcar to have been heavily involved in the deer hide trade with the French.

Differences in the kinds of decorated ceramics found on these sites, as well as preferences in the use and manufacture of shcll-tempered vessels, suggest scveral different groupings of Caddo sites that may provisionally be associatcd with the known locations of specific Caddo tribes. This would include pre1720 Nasoni Caddo groups on Black Bayou and in the Hatchel site environs as wcll as possibly on the lower Sulphur (although here shell-tempered pottcry was apparently relatively abundant in domestic and mortuary contexts), the Kadohadacho at Roseborough Lake, and perhaps the upper Natchitoches in the vicinity of the Indian Springs \#2 site (see Figure 2). In the case of the Caddo groups living in the Mound Prairie arca at the mouth of the Kiamichi River and those more distant Caddo living at the Womack site, thcir Caddo tribal or ethnic affiliation is not known. Hopefully future work along the Red River and lower Sulphur River will clarify these ethnic attributions and material culture trends as well as acquirc more substantive information about the Historic Caddo archaeological record in this part of Northeast Texas.

\section{REFERENCES CITED}

Banks, L. D. and N. T. Banks

2002 Last Twentieth Century Archeological Investigations at the Arnold Roitsch Site (4IRRI6), Red River County, Texas. Final report prepared in fulfillment of Texas Antiquities Permit No. 2179. 
Bond, J. (editor)

2006 Art of the Ancient Caddo. Grove Hill Publishing, Leonard, Texas.

Gilmore, K.

1986 French-Indian Interaction at an Early Eighteenth Century Post: The Roseborough Lake Site, Bowie County, Texas. Contributions in Archaeology 3. Institute of Applied Sciences, North Texas State University, Denton.

1991 An Archeological Footnote to History. Bulletin of the Texas Archeological Society 60:303-324.

Gonzalez, B., R. Cast, T. K. Perttula, and B. Nelson

2005 A Rediscovering of Caddo Heritage: The W. T. Scott Collection at the American Museum of Natural History and Other Caddo Collections from Arkansas and Louisiana. Historic Preservation Program, Caddo Nation of Oklahoma, Binger, Oklahoma.

Harris, R. K.

1953 The Sam Kaufman Site, Red River County, Texas. Bulletin of the Texas Archeological Society 24:4368.

Harris, R. K., I. M. Harris, and P. Miroir

1980 The Atlanta State Park Site in Northeastern Texas. Louisiana Archaeology 6:223-230.

Harris, R. K., I. M. Harris, J. C. Blaine, and J. Blaine

1965 A Preliminary Archeological and Documentary Study of the Wonack Site, Lamar County, Texas. Bulletin of the Texas Archeological Society 36:287363.

Kelley, D. B. and M. J. Guccione

2000 Cultural Resources Survey and Evaluation of Portions of the Moore/Higginbotham Site (3MI3/30), Within Item 2 of the Red River Below Denison Dam Levee Rehabilitation/Restoration Project, Miller County, Arkansas. Coastal Environments, Inc., Baton Rouge.

Middlebrook, T.

2007 A Survey of Historic Caddo Sites in Nacogdoches County. Journal of Northeast Texas Archaeology 26:99-115.

Miroir, M. P., R. K. Harris, J. C. Blaine, and J. McVay

1975 Benard de la Harpe and the Nassonite Post. Bulletin of the Texas Archeological Society 44:113-167.

Perino, G.

1981 Archeological Investigations at the Roden Site (MC215), McCurtain County, Oklahoma. Potsherd Press No. 1. Museum of the Red River, Idabel, Oklahoma.

1983 Archaeological Research at the Bob Williams Site (4IRRI6), Red River County, Texas, Museum of the Red River, Idabel, Oklahoma.
Perttula, T. K.

2005 The Indian Springs \#2 Site (41BW512): A Late $18^{\text {th }}$ Century Kadohadacho Settlement in Northeastern Texas. Journal of Northeast Texas Archaeology 22:39-52.

2007a Kinsloe Focus Artifact Assemblages and Nadaco Caddo. Journal of Northeast Texas Archaeology 26:116-119.

2007b Inverted Rim Engraved Vessels in Protohistoric and Early Historic Caddo Sites in parts of Northeast Texas. Journal of Northeast Texas Archaeology 26:136-144.

2008 (editor) The Archeology of the Roitsch Site (4lRR16), an Early to Historic Caddo Period Village on the Red River in Northeast Texas. In Collected Papers from Past Texas Archeological Society Sum. mer Field Schools, edited by T. K. Perttula, pp. 313628. Special Publication No. 5. Texas Archeological Society, San Antonio.

Perttula, T. K. and L. Green

2006 Marine Shell Ear Disks from Protohistoric Caddo Sites on Stouts Creek, Hopkins County, Texas. Journal of Northeast Texas Archaeology 25:19-25.

Perttula, T. K. and B. Nelson

2003 Archeological Investigations of Village Areas at the Hatchel Site (4IBW3), Bowie County, Texas. Report of Investigations No. 58. Archeological and Environmental Consultants, LLC, Austin.

Perttula, T. K., J. E. Bruseth, N. A. Kenmotsu, D. J. Prikryl, W. A. Martin, L. Banks, J. Smith, N. G. Reese, and S. A. Iruegas

2001 Archeological Investigations on the Red River and Tributaries: Summary of the Findings of the 1991 and 1992 The Journal of Northeasl Texas Archaeology Field School in Red River and Lamar Counties, Texas. Bulletin of the Texas Archeological Society 72:165-250.

Sierzchula, M. C., M. J. Guccione, R. H. Lafferty III, and M. T. Oates

1995 Archeological Investigations in the Great Bend Region, Miller County, Arkansas, Levee Items 2 and 3. Report 94-5. Mid-Continental Research Associates, Inc., Lowell, Arkansas.

Skinner, S. A., R. K. Harris, and K. M. Anderson (editors) 1969 Archaeological Investigations at the Sam Kaufman Site, Red River County, Texas. Contributions in Anthropology No. 5. Department of Anthropology, Suuthern Methodist University. Dallas.

Smith, M. T.

2002 Eighteenth-Century Glass Beads in the French Colonial Trade. Historical Archaeology 36(1):55-61. 
Swanton, J. R.

1942 Source Material on the History and Ethnology of the Caddo Indians. Bulletin No. 132. Bureau of American Ethnology, Smithsonian Institution, Washington, D.C.

Wedel, M. M.

1978 La Harpe's 1719 Post on Red River and Nearby Caddo Settlements. Bulletin 30. Texas Memorial Museum, Austin.
Williams, S. and F. Schambach

2002 The Lower Mississippi Valley and its Westward Connections, as Seen from the Oliver Site. MS on file, Arkansas Archeological Survey, Southern Arkansas University, Magnolia, Arkansas. 